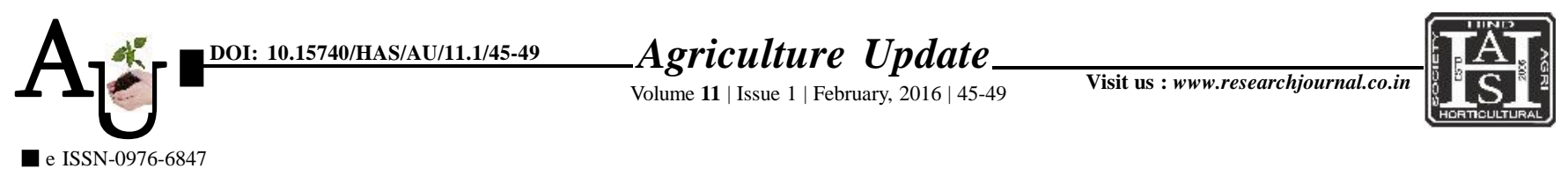

\title{
Research Article: Determinants of brand preference in drip irrigation system with special reference to Coimbatore district
}

R. RAVIKUMAR AND DAVID WINSTER PRAVEENRAJ

Article Chronicle: Received :

22.08.2014;

Revised :

03.01.2016;

Accepted :

17.01.2016

KEY WoRds:

Determinants,

Brand preference,

Drip irrigation system

Author for correspondence :

\section{R. RAVIKUMAR}

School of Management Studies, Bannari Amman Institute of Technilogy (A.U.) SATHYAMANGALAM (T.N.) INDIA

Email: raviagrimba@ gmail.com

See end of the article for authors' affiliations
SUMMARY : Agricultural sector is the largest water user of the country, the growing challenge for agricultural development is how to grow more food for growing population with less water share for agriculture. The government also implemented subsidy schemes to encourage the farmers to adopt improved irrigation technologies. This gives greater opportunity to drip irrigation companies to market their products by improving their brand image. This study would focus on determinants of brand preference in drip irrigation system by analyzing the data collected from 100 randomly selected farmers from five blocks of Coimbatore district using percentage analysis, factor analysis, Logit regression, Garrett ranking and likert scale analysis. The study reveals that water saving and labour cost were the most influencing factor for the adoption of drip irrigation system. Immediate response by sales executives, market promotion, peer group influence, quality of materials and price were the major determinants of brand preference of farmers. The farmers were satisfied with the price, availability of spare parts and government subsidies but highly unsatisfied with after sales service provided by the marketers of drip system.

How to cite this article : Ravikumar, R. and Praveenraj, David Winster (2016). Determinants of brand preference in drip irrigation system with special reference to Coimbatore district. Agric. Update, 11(1): 45-49. 